\title{
US Congress says climate is part of politics
}

\section{Washington}

Political efforts are under way in Washington to bring into the policy arena the depletion of the atmospheric ozone layer warming due to the greenhouse effect. Declaring that the topics "can no longer be treated solely as important scientific questions", Senator John Chafee (Republican, Rhode Island), chairman of the Senate subcommittee on environmental pollution, last week announced that he would ask the Environmental Protection Agency (EPA) and Congress's Office of Technology Assessment to conduct studies of policy options to stabilize world levels of atmospheric gases. start of two days of hearings at which administration officials and prominent scientists were called to give evidence on the problem and their views of appropriate responses. Chafee also said he would ask the National Academy of Sciences to review gaps in scientific knowledge on the topic, and that he would ask the State Department to bring the issue to international attention.

Although administration officials at the hearings generally stuck to the line that more research is needed before policy
Chafee's statement was made at the

options can be considered, EPA administrator Lee Thomas said a working group has been established within the agency to estimate trends in greenhouse gas emissions and to determine possible control options. The working group will also conduct long-term research.

EPA is already considering further controls on the use of chlorofluorocarbons (CFCs), which catalyse the breakdown of the ozone layer; a decision will be made by November 1987. Several witnesses referred to recent measurements showing a 40 per cent reduction in the ozone layer over Antarctica, the causes of which remain unknown but which may be related to human activities.

Concern over the effects of CFCs on the ozone layer led the United States in 1978 to ban their use in non-essential aerosol sprays, but EPA has failed to persuade other nations to follow suit. Thomas said EPA had "stepped back" from those efforts, but it is considering regulations further to limit domestic uses of CFCs, used mainly as refrigerants.

Several witnesses at last week's hearings referred to the need for international cooperation on research, including Thomas and Alvin Trivelpiece, director of the

\section{French universities}

\section{One reform too many?}

FRENCH university presidents walked out of a meeting with the new research and higher education minister, Alain Devaquet, last week, after hearing that France is to abandon its newly-created $\mathrm{PhD}$ degree, much welcomed by natural scientists for its similarities to the research degrees of Britain and the United States. The plan is to return to the old idiosyncratic system of "troisième cycle" and "thése d'Etat" degrees.

This is just one of the reforms promised last week by Devaquet, a physicist, in a new law for the universities to be put before the National Assembly before the summer. Another reform will allow universities to select their own students, the first such selection system allowed in France since the European university revolution of 1968 . But the selection will be only nominal: Devaquet, no doubt fearful of the political consequences of avowing selection, has also reaffirmed the right of every school-leaver who passes the coveted "baccalaureate" to gain a university place, just as each of them can do at present. It will be up to local education authorities to square this selective circle.

Other promised reforms include a lightening of the system of the three elective councils by which universities and their departments are managed, in order to give more power to professors ("and less to cleaning staff", according to one supporter), but the present national system for awarding degrees will be retained.

The law thus does not go so far as the promise of Prime Minister Jacques Chirac to return autonomy to the universities both in the selection of students and the awarding of degrees. But it went far enough for the university presidents to walk out of their meeting with Devaquet, which was held just a couple of hours before the minister's previously arranged press conference on the new law. The presidents were protesting at an almost total lack of consultation in the brief preparation of the law since the general elections in March, and at the prospect of yet another long hot summer of discontent as the French university system is yet again lifted up by the roots to see how the fragile plant is growing.
Robert Walgate office of energy research at the Department of Energy (DoE). DoE is concluding an agreement on joint climate research with China, to be conducted through the Chinese Academy of Sciences. Other countries are participating in DoE's carbon dioxide research programme.

A scientific view of the problems was provided by James Hansen of the National Aeronautics and Space Administration (NASA)'s Goddard Space Flight Center. Hansen has used a global climatic model to simulate the climatic effect of the transient growth of atmospheric carbon dioxide and other trace gases now thought collectively to be as important.

Among Hansen's results is the conclusion that a large part of the equilibrium warming due to the well-documented carbon dioxide increase since 1850 has probably not yet occurred; the same is true for the other gases. The effect of warming will start to emerge from statistical background noise in the $1990 \mathrm{~s}$.

In response to submitted questions, Hansen also prepared estimates of the increased number of days per year over 90 degrees Fahrenheit in Washington DC that would result from a doubling of carbon dioxide. Conclusion: from 35 days (at present) to 85 , with 12 of them over 100 degrees. Temperature across much of the United States might rise by an average of 3 degrees Fahrenheit or more by 2020 . Local press, sweltering in 90-degree-plus weather, were duly impressed.

Hansen said later in an interview that he was surprised at Chafee's call for immediate studies of policy options; he would prefer to emphasize the need for integrated and long-term studies of climate systems as he thought policy options would not meet political approval in the absence of clearer evidence. Recommendations along these lines have been made in a report to be published by the NASA Earth System Sciences Committee chaired by Francis Bretherton of the National Center for Atmospheric Research. But, while also stressing the need for more research, Bretherton said he approved of Chafee's call for an assessment of policy options.

Although the greenhouse effect is not at present under specific consideration in the White House, a consensus is emerging in the scientific community on the need for coordinated and long-term measurements of climate. An international initiative has been proposed by the International Council of Scientific Unions, and the roles of US federal agencies in a long-term climate study are being considered in the administration by the Senior Inter-agency Group on Space, called SIG-Space. A major international conference on the subject sponsored by the United Nations Environment Programme and EPA takes place this week in Arlington, Virginia.

Tim Beardsley 